\title{
Foreword
}

By its example, Charles Musser's elegantly argued study of Edwin S. Porter conveys two of the primary goals that the UCLA Film and Television Archive seeks to achieve in sponsoring scholarly publication.

In part we hope to underline the creative role played by film archives in making historical research possible and, often, in helping to set the field's scholarly agenda. The study of early cinema is reliant on the accessibility of films rescued and preserved by institutions such as the Museum of Modern Art, the Library of Congress, the International Museum of Photography, and the UCLA Film and Television Archive. The current worldwide revival of scholarly concern with early film can be traced back to the legendary symposium sponsored by the International Federation of Film Archives in Brighton, England, in 1978.

Our second goal in promoting scholarly publication is to celebrate and promote the renaissance of historical writing currently taking place in the field of film and television studies. After a long period of marginalization to the outer fringes of the discipline, serious historical research is now being rediscovered, redefined, and legitimated by a new generation of young scholars like Charles Musser.

In his writing Musser combines the traditionalist historian's respect for scholarly erudition with the contemporary historian's insistence on methodological self-consciousness, multidisciplinary discourse, and intellectual risktaking. Relying almost entirely on primary archival source materials to construct his arguments, Musser rejects timeworn and reductive explanations of historical causality such as auteurism and technological determinism. His dialectical approach to historical narrative freely crosses disciplinary boundaries to convey the complex interplay of aesthetics with a multifaceted social and industrial context. 


\section{x Foreword}

In theory, the vast holdings of film and documents available through the nation's archives suggest the possibility of doing historical research that is truly definitive - the "last word" in the field. In practice, the current generation of intellectually expansive scholars are much too aware of the complexity of history to believe that interpretive closure is possible. In his commitment to both exhaustive archival research and audacious interpretation, Charles Musser exemplifies the creative potential in this contradiction.

Robert Rosen

Director

UCLA Film and Television Archive 